\title{
Persistent plasminogen activator inhibitor 1 gene expression in cardiac transplant recipients with idiopathic dilated cardiomyopathy
}

\author{
Romana Schäfer, PhD, ${ }^{a}$ Katharina Krenn, MD, ${ }^{\text {a,b }}$ Matthias Gmeiner, MD, ${ }^{\mathrm{a}, \mathrm{c}}$ Dietmar Abraham, PhD, ${ }^{\mathrm{a}}$ and \\ Seyedhossein Aharinejad, MD, $\mathrm{PhD}^{\mathrm{a}, \mathrm{c}}$
}

\begin{abstract}
Objectives: Plasminogen activator inhibitor 1 is the primary regulator of urokinase plasminogen activator and tissue plasminogen activator. Plasminogen activator inhibitor 1 is essential in the control of the thrombotic/fibrinolytic balance and is a marker of endothelial cell injury. Idiopathic dilated cardiomyopathy is reportedly associated with endothelial cell dysfunction. Whether endothelial cell damage plays a role in patients with dilated cardiomyopathy after cardiac transplantation remains unknown.
\end{abstract}

\begin{abstract}
Methods: In this study explanted hearts of cardiac transplant recipients with ischemic cardiomyopathy and dilated cardiomyopathy, as well as control myocardial tissue, were investigated for expression of urokinase plasminogen activator, tissue plasminogen activator, urokinase plasminogen activator receptor, and plasminogen activator inhibitor 1 and 2. Furthermore, plasminogen activator inhibitor 1 expression was examined in endomyocardial biopsy specimens and sera of patients with ischemic cardiomyopathy and those with dilated cardiomyopathy during the first posttransplantation year. The effect of the patient's serum on endothelial cells was assessed in vitro to examine the role of circulating endothelial cell damage-related factors.
\end{abstract}

\begin{abstract}
Results: Plasminogen activator inhibitor 1 expression was upregulated in ischemic cardiomyopathy and dilated cardiomyopathy myocardial tissue versus that seen in control tissue. After transplantation, plasminogen activator inhibitor 1 expression returned to control levels in patients with ischemic cardiomyopathy. In patients with dilated cardiomyopathy, plasminogen activator inhibitor 1 expression increased at 24 weeks after transplantation in both biopsy specimens and sera versus that seen in control tissue. Sera of patients with dilated cardiomyopathy, but not that of patients with ischemic cardiomyopathy, inhibited vascular endothelial growth factor A-induced proliferation of endothelial cells, although downstream target gene activation of early growth response factor 1 and NGFI-A binding protein 2 was not affected.
\end{abstract}

Conclusions: These data suggest for the first time that the endothelial cell damage-related process recurs in patients with dilated cardiomyopathy after transplantation, which, independently of vascular endothelial growth factor, is associated with increased plasminogen activator inhibitor 1 expression, and that this pathology might play a role in allograft remodeling in patients with dilated cardiomyopathy. (J Thorac Cardiovasc Surg 2010;139:1644-51)

Plasminogen activator inhibitor (PAI) 1 is a key regulator of the plasminogen activation system, a proteolytic cascade implicated in various physiological and pathophysiological processes, including vascular thrombolysis, inflammation, wound healing, tumor invasion, and neovascularization. ${ }^{1} \mathrm{PAI}-1$ is the primary regulator of the plasminogen activators urokinase plasminogen activator (uPA) and tissue plasminogen activator (tPA) and is essential in control of the physiological thrombotic/fibrinolytic balance. ${ }^{2}$ Prothrombotic and fibrinolytic

From the Laboratory for Cardiovascular Research, ${ }^{\mathrm{a}}$ Center for Anatomy and Cell Biology, the Department of Internal Medicine II, ${ }^{b}$ and the Department of Cardiothoracic Surgery, ${ }^{\mathrm{c}}$ Medical University of Vienna, Vienna, Austria.

Supported by grant no. P22371-B19 of the Austrian Science Foundation to S. Aharinejad.

Disclosures: None.

Received for publication July 16, 2008; revisions received Aug 19, 2009; accepted for publication Sept 8, 2009; available ahead of print April 15, 2010.

Address for reprints: Seyedhossein Aharinejad, MD, PhD, Department of Cardiothoracic Surgery, Medical University of Vienna, Waehringer Guertel 18-20, A-1090,

Vienna, Austria (E-mail: seyedhossein.aharinejad@meduniwien.ac.at).

$0022-5223 / \$ 36.00$

Copyright (c) 2010 by The American Association for Thoracic Surgery doi:10.1016/j.jtcvs.2009.09.071 pathways are also essential in the development of various cardiovascular diseases..$^{3-5}$ A second inhibitor of the plasminogen activation system is PAI-2, the biologic role of which in the cardiovascular system is unclear. Only in tumor biology has PAI-2 been shown to play the opposite role versus PAI- $1 .{ }^{6}$

Epidemiologic studies have indicated that high plasma levels of PAI-1 constitute a risk factor for ischemic heart disease caused by impaired thrombolysis and have also been associated with atherosclerosis by affecting matrix remodeling. ${ }^{3}$ PAI-1 is expressed by various cell types, including endothelial cells (ECs), smooth muscle cells, fibroblasts, inflammatory cells, and platelets, ${ }^{2}$ and is upregulated by inflammatory cytokines, such as interleukin 1 , tumor necrosis factor $\alpha$, or transforming growth factor (TGF) $\beta .^{3}$ Apart from the intravascular compartment, PAI1 is also present in the subendothelial extracellular matrix (ECM), where it controls local proteolysis through inhibition of plasminogen activators and orchestrates cell adhesion and migration through interaction with integrins and ECM components. Increased PAI-1 production and a subsequent increase in thrombogenicity are important components of 


\begin{tabular}{|c|c|}
\hline \multicolumn{2}{|c|}{ Abbreviations and Acronyms } \\
\hline DCM & $=$ dilated cardiomyopathy \\
\hline EC & $=$ endothelial cell \\
\hline ECM & $=$ extracellular matrix \\
\hline EGR & $=$ early growth response \\
\hline ET & $=$ endothelin \\
\hline HDM & $\begin{aligned}= & \text { human dermal microvascular } \\
& \text { endothelial cells }\end{aligned}$ \\
\hline ICM & $=$ ischemic cardiomyopathy \\
\hline NAB & $=$ NGFI-A binding protein \\
\hline PAI & $=$ plasminogen activator inhibitor \\
\hline TGF & $=$ transforming growth factor \\
\hline tPA & $=$ tissue plasminogen activator \\
\hline uPA & $=$ urokinase plasminogen activator \\
\hline uPAR & $\begin{aligned}= & \text { urokinase plasminogen activator } \\
& \text { receptor }\end{aligned}$ \\
\hline VEGF & $=$ vascular endothelial growth factor \\
\hline
\end{tabular}

endothelial dysfunction. ${ }^{7}$ The interplay between PAI-1 and ECs is critical for angiogenesis, and this process is primarily mediated through uPA-antiproteinase interactions. ${ }^{2}$

Regulators of ECM composition and EC survival, such as endothelin (ET) 1 and TGF- $\beta$, are key factors that are dysregulated in patients with idiopathic dilated cardiomyopathy (DCM),${ }^{8,9}$ and in combination with PAI-1, they can reflect the extent of endothelial damage. ${ }^{10}$ DCM, similar to ischemic cardiomyopathy (ICM), is one of the leading causes of heart failure in patients undergoing cardiac transplantation. It has been demonstrated that PAI- 1 activity in the blood of heart transplant recipients increases at 6 months after transplantation, ${ }^{11}$ and the resulting hypofibrinolytic condition has been discussed as a risk factor of allograft vasculopathy. ${ }^{11,12}$ The issue of whether and how the UPA/uPA receptor (UPAR)/ PAI-1 system affects ECM-related homeostasis and EC survival in cardiac allografts in patients with DCM has remained unclear. We addressed this issue.

\section{MATERIALS AND METHODS \\ Patients and Tissue Sampling}

In this study, which was approved by the Ethics Committee of the Medical University of Vienna, a total of 84 patients with heart failure who provided informed consent to be enrolled, including those with idiopathic DCM $(n=60)$ and ICM $(n=24)$, were studied. All patients had been scheduled for cardiac transplantation between 1999 and 2003 and provided informed consent to be enrolled. The control group consisted of 12 donors with no history of cardiac disease whose hearts could not be transplanted for quality reasons. Table 1 summarizes the demographic and most important clinical data of the patients. Patients with myocardial infarction (6 months before surgical intervention) or echocardiographic evidence of valvular diseases caused by ischemic heart disease were excluded from the study. Patients with idiopathic DCM were routinely screened for the (unlikely) presence of coronary artery disease, and the patients with DCM included in the present study were free from coronary artery disease. Multiple myocardial bi- opsy specimens were taken from the anterior aspect of the left ventricle. The selection criteria for final inclusion of the biopsy specimens into the study were preoperative, as follows. Biopsy specimens were taken $2 \mathrm{~cm}$ distal to the diagonal branch and $2 \mathrm{~cm}$ from the left anterior descending coronary artery. If the left anterior descending coronary artery was occluded, resulting in myocardial infarction and scarring as confirmed by means of coronary angiographic and echocardiographic analysis, the patient was excluded from the study. These preoperative criteria helped us to differentiate between necrotic or scar tissue (excluded) and ischemic myocardium (included into this study). Endomyocardial biopsy specimens from the grafted hearts and serum samples were obtained at 1, 2, 3, 4, 6, 12, 24, and 52 weeks after transplantation and snap-frozen for molecular analyses. Table 2 shows pretransplantation and posttransplantation medication, as well as the immunosuppression regimen of the study patients.

\section{Real-Time Reverse Transcription Polymerase Chain Reaction}

RNA was isolated from myocardial tissue, and polymerase chain reaction was performed, as previously described. ${ }^{13}$ The primer sequences used for target genes were as follows (sense/antisense): $u P A, 5^{\prime}$-CCAGTTTGGCA CAAGCTG-3'/5'-GAGACTCTCGTGTAGACG-3'; $t P A, \quad 5^{\prime}$-CGACAAT GACATTGCGCT-3'/5'-CACAGCATGTTGTCGG-3'; $u$ PAR, 5'-CAGTGT TACAGCTGCAAG-3' $3^{\prime} / 5^{\prime}$-CACTTTTAGTACAGCAGG-3' ${ }^{\prime}$; $P$ AI- $1,5^{\prime}$-GGA AAGGCAACATGACCA- $3^{\prime} / 5^{\prime}$-GAGACTATGACAGCTGTG- $3^{\prime} ; \quad P A I-2$, 5'-CCAGCAAAGACAAAATGGC-3' $/ 5^{\prime}$-CCCTGTCATAACACCTCC-3'; early growth response (EGR) 1, 5'-AGGACAAGAAAGCAGACAAAAG$3^{\prime} / 5^{\prime}$-ATAAGAGGTAGTAACCGGGGAC-3'; NGFI-A binding protein (NAB) 2: 5'-TGGTGGAAAGTGTGGAGAGG-3'/5'-CGAAACGGCCATA GATGATG-3'; TGFB: $5^{\prime}$-ATGACAAGTTCAAGCAGAG-3' ${ }^{\prime} / 5^{\prime}$-CACTTG CAGTGTGTTATCC-3'; ET-1, 5'-GGAAAAGACTGTTCCAAGC-3'/5'-G GTTGTGGGTCACATAACG- $3^{\prime}$; and $\beta_{2}$-microglobulin, $5^{\prime}$-GATGAGTAT GCCTGCCGTGTG-3' $3^{\prime} / 5^{\prime}$-CAATCCAAATGCGGCATCT-3'. LCDA Version 3.1.102 software (Roche, Mannheim, Germany) was used for polymerase chain reaction data analysis. The specificity of the amplification product was determined by performing a melting curve analysis. Standard curves for expression of each gene were generated by serial dilution of known quantities of the respective cDNA gene template. Relative quantification of the signals was done by normalizing the signals of the different genes with the $\beta_{2}$-microglobulin signal. Measurements were done in triplicate.

\section{Western Blotting}

Tissue was solubilized, and Western blotting was performed, as previously described. ${ }^{13}$ The blots were probed with antibodies against uPA (mouse monoclonal; Oncogene, Darmstadt, Germany) and PAI-1 (rabbit polyclonal; Santa Cruz, Santa Cruz, Calif) before incubation with horseradish peroxidase-conjugated secondary antibodies (Amersham, Buckinghamshire, United Kingdom). Proteins were immunodetected on the membrane by using chemiluminescence (Supersignal-West-Femto; Pierce, Rockford, Ill), and specific protein bands were quantified with Easy plus Win 32 software (Herolab, Wiesloch, Germany).

\section{Organ Culture}

Freshly isolated myocardial tissue (approximately 2-3 $\mathrm{mm}^{3}$ ) from patients with DCM and ICM was incubated in Dulbecco's modified Eagle's medium containing $10 \%$ fetal calf serum, as previously described. ${ }^{13}$ Six hours after isolation, wells were stimulated with $100 \mathrm{ng} / \mathrm{mL}$ vascular endothelial growth factor (VEGF) A (Promokine, Heidelberg, Germany), followed by incubation for 24 hours and RNA isolation. Experiments were performed in triplicate. Additionally, aortic ECs, smooth muscle cells, and cardiomyocytes were isolated for RNA analyses. ${ }^{8,9}$

\section{EC Culture}

Human dermal microvascular endothelial cells (HDMVECs) were cultured in EGM-2 MV medium (Lonza, Basel, Switzerland) plus 10\% fetal 
TABLE 1. Demographic and selected echocardiographic data and posttransplantation outcome parameters of patients

\begin{tabular}{|c|c|c|c|}
\hline & $\begin{array}{l}\text { Controls } \\
(\mathrm{n}=12)\end{array}$ & $\begin{array}{c}\text { ICM } \\
(\mathbf{n}=\mathbf{2 4})\end{array}$ & $\begin{array}{c}\text { DCM } \\
(\mathbf{n}=60)\end{array}$ \\
\hline \multicolumn{4}{|l|}{$\begin{array}{l}\text { Pretransplantation } \\
\text { parameters }\end{array}$} \\
\hline Age, y & $41 \pm 7$ & $49 \pm 6$ & $47 \pm 4$ \\
\hline Sex, M/F & $10 / 2$ & $20 / 4$ & $34 / 26$ \\
\hline NYHA class, III/IV & - & $14 / 10$ & $38 / 22$ \\
\hline Body surface area, $\mathrm{m}^{2}$ & $1.81 \pm 0.14$ & $1.83 \pm 0.14$ & $1.81 \pm 0.20$ \\
\hline LVEDDI, mm/mm² & $25.6 \pm 1.7$ & $37.8 \pm 3.9^{*}$ & $45.0 \pm 7.1^{* \prime} \dagger$ \\
\hline LVEDV, mL & $64 \pm 2$ & $177 \pm 9 *$ & $284 \pm 10^{*} \dagger$ \\
\hline Ejection fraction, $\%$ & $72 \pm 6$ & $22 \pm 7 *$ & $18 \pm 6^{*}$ \\
\hline $\begin{array}{l}\text { Cardiac index, } \\
\qquad \mathrm{L} / \mathrm{m}^{2} \times \min ^{-1}\end{array}$ & $3.09 \pm 0.28$ & $2.14 \pm 0.41^{*}$ & $2.01 \pm 0.38^{*}$ \\
\hline Mean PAP, mm Hg & $15.5 \pm 2.0$ & $27.8 \pm 6.8^{*}$ & $34.7 \pm 10.1^{*}$ \\
\hline PCWP, mm Hg & $4.6 \pm 1.4$ & $20.4 \pm 5.4^{*}$ & $21.0 \pm 6.8^{*}$ \\
\hline \multicolumn{4}{|l|}{ Outcome parameters } \\
\hline 3-mo Mortality & - & $12.5 \%$ & $13.3 \%$ \\
\hline 1-y Mortality & - & $20.8 \%$ & $13.3 \%$ \\
\hline 5-y Mortality $(\mathrm{n}=76)$ & - & $21.1 \%(\mathrm{n}=19)$ & $20.8 \%(n=48$ \\
\hline $\begin{array}{l}\text { Rejection }(>\text { grade } 0) \\
\text { incidence in 3-mo } \\
\text { survivors in first } \\
\text { posttransplantation } \\
\text { year }\end{array}$ & - & $41.7 \%$ & $50.0 \%$ \\
\hline $\begin{array}{l}\text { Cardiac allograft } \\
\text { vasculopathy } \\
\text { incidence in 3-mo } \\
\text { survivors, } 5 \text { y after } \\
\text { transplantation } \\
(\mathrm{n}=65)\end{array}$ & - & $11.8 \%(\mathrm{n}=17)$ & $12.5 \%(\mathrm{n}=40$ \\
\hline
\end{tabular}

ICM, Ischemic cardiomyopathy; $D C M$, dilated cardiomyopathy; NYHA, New York Heart Association; $L V E D D I$, left ventricular end-diastolic diameter index; $L V E D V$, left ventricular end-diastolic volume; $P A P$, pulmonary arterial pressure; $P C W P$, pulmonary capillary wedge pressure. ${ }^{*} P<.05$ versus control subjects. $\dagger^{\dagger} P<.05$ versus patients with ICM.

bovine serum. Cells were isolated, as previously described. ${ }^{8}$ HDMVECs were grown in EGM-2 MV medium supplemented with serum from patients with DCM and ICM and healthy control subjects for 24 and 48 hours and then stimulates with $100 \mathrm{ng} / \mathrm{mL}$ recombinant VEGF-A (Promokine) for 45 minutes, followed by RNA and protein isolation. Experiments were performed in triplicate.

\section{Proliferation Assay}

HDMVECs were seeded on 96-well plates at a density of 10,000 cells per well in EGM-2 MV supplemented with $10 \%$ fetal bovine serum. Culture medium was replaced with EGM-2 MV medium supplemented with serum (before transplantation and 4 and 52 weeks after transplantation) from patients with DCM and ICM and healthy control subjects and then stimulated with $100 \mathrm{ng} / \mathrm{mL}$ recombinant VEGF-A (Promokine). The cultures were maintained for an additional 24 or 48 hours for each treatment and time point in quadruplicate. Cell proliferation was determined by using the WST-1 reagent (Roche Diagnostics, Indianapolis, Ind), according to the manufacturer's protocol. ${ }^{14}$

\section{Data Analysis}

We used analysis of variance with the Bonferroni post hoc test and the Wilcoxon rank test to compare the data between the groups. Regression analysis was performed to assess differences among the time points of pa-
TABLE 2. Pretransplantation and posttransplantation medication of the study patients

\begin{tabular}{|c|c|c|c|}
\hline Characteristic & $\begin{array}{c}\text { All } \\
\text { patients } \\
(\mathrm{n}=93)\end{array}$ & $\begin{array}{c}\text { Patients } \\
\text { with DCM } \\
(\mathbf{n}=60)\end{array}$ & $\begin{array}{c}\text { Patients } \\
\text { with ICM } \\
(\mathrm{n}=\mathbf{2 4})\end{array}$ \\
\hline \multicolumn{4}{|l|}{ Diabetes mellitus } \\
\hline Absent & 44 & 27 & 13 \\
\hline IDDM & 12 & 9 & 3 \\
\hline NIDDM & 37 & 24 & 8 \\
\hline \multicolumn{4}{|l|}{ Pretransplantation medication } \\
\hline Statin, yes/no & $32 / 61$ & $11 / 49$ & $19 / 5$ \\
\hline ACE inhibitor, yes/no & $69 / 24$ & $44 / 16$ & $20 / 4$ \\
\hline $\begin{array}{l}\text { AT II receptor } \\
\text { inhibitor, yes/no }\end{array}$ & $24 / 69$ & $17 / 43$ & $5 / 19$ \\
\hline PGE, yes/no & $29 / 64$ & $19 / 41$ & $8 / 16$ \\
\hline Digitalis, yes/no & $40 / 53$ & $32 / 28$ & $6 / 18$ \\
\hline Coumarin, yes/no & $61 / 32$ & $40 / 20$ & $17 / 7$ \\
\hline Amiodarone, yes/no & $39 / 54$ & $33 / 27$ & $4 / 20$ \\
\hline$\beta$-blocker, yes/no & $72 / 21$ & $46 / 14$ & $21 / 3$ \\
\hline Nitroglycerine, yes/no & $10 / 83$ & $5 / 55$ & $5 / 19$ \\
\hline \multicolumn{4}{|l|}{ Posttransplantation medication } \\
\hline ACE inhibitor, yes/no & $26 / 68$ & $15 / 45$ & $8 / 16$ \\
\hline Statin, yes/no & $55 / 38$ & $30 / 30$ & $20 / 4$ \\
\hline \multicolumn{4}{|l|}{ Immunosuppression* } \\
\hline Cyclosporine + azathioprine & 9 & 6 & 3 \\
\hline Tacrolimus + azathioprine & 2 & 1 & 1 \\
\hline $\begin{array}{l}\text { Cyclosporine }+ \text { mycophenolate } \\
\text { mofetil }\end{array}$ & 47 & 29 & 12 \\
\hline $\begin{array}{l}\text { Tacrolimus + mycophenolate } \\
\text { mofetil }\end{array}$ & 16 & 9 & 6 \\
\hline Cyclosporine + everolimus & 5 & 3 & 1 \\
\hline Other combinations & 14 & 12 & 1 \\
\hline
\end{tabular}

$D C M$, dilated cardiomyopathy; ICM, Ischemic cardiomyopathy; IDDM, insulindependent diabetes mellitus; NIDDM, non-insulin-dependent diabetes mellitus; $A C E$, angiotensin converting enzyme; $A T$, angiotensin; $P G E$, prostaglandin E. *All patients received steroids, as previously described. ${ }^{8}$

tients with DCM and ICM undergoing transplantation. All statistical tests were 2-sided. Data are expressed as means \pm standard deviations. Statistical tests were performed with the use of SPSS software (version 10.0.7; SPSS, Inc, Chicago, Ill).

\section{RESULTS \\ Selective Upregulation of PAI-1 mRNA and Protein Expression in Patients With DCM}

The myocardial mRNA expression of $u P A, t P A, u P A R$, and $P A I-2$ was unchanged in both patient groups, whereas myocardial mRNA expression of $P A I-1$ was significantly upregulated in patients with DCM and ICM versus that seen in control subjects $(P<.05$; Figure $1, A)$. The protein expression of pro and active uPA was unchanged in both patients with DCM and those with ICM compared with that seen in control myocardial biopsy specimens. Only in patients with DCM was pro PAI-1 and PAI-1 protein expression significantly increased compared with that seen in control subjects $(P<.05$; Figure $1, B)$. 

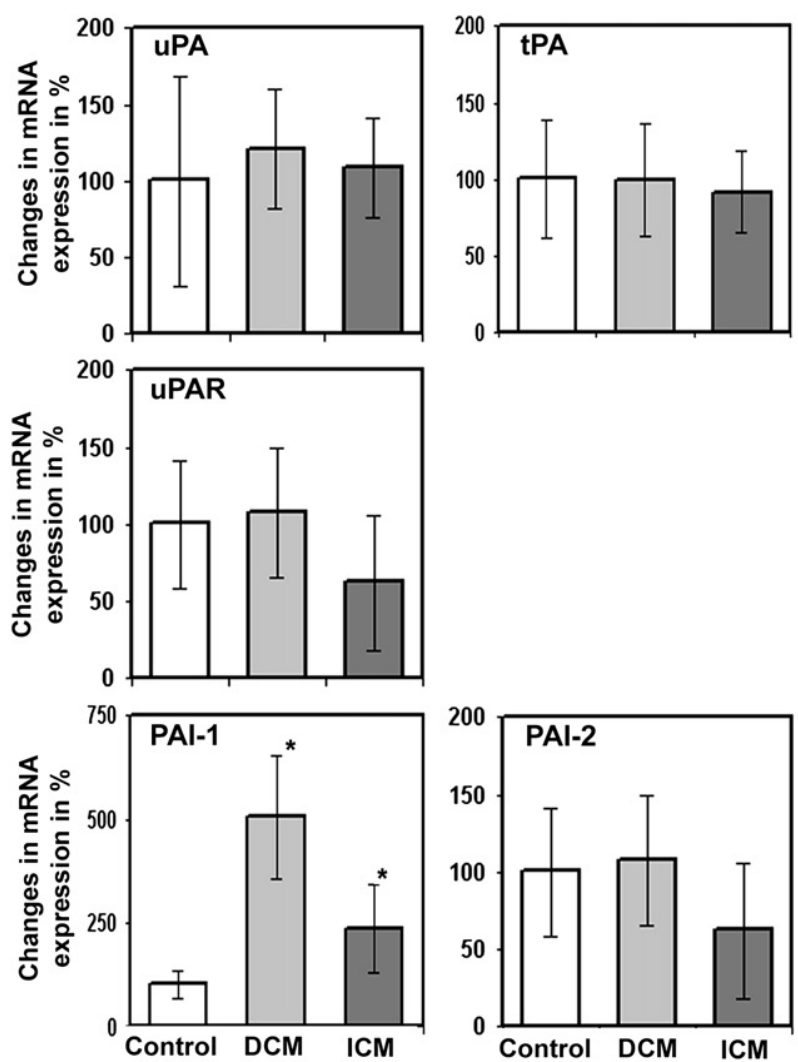

A
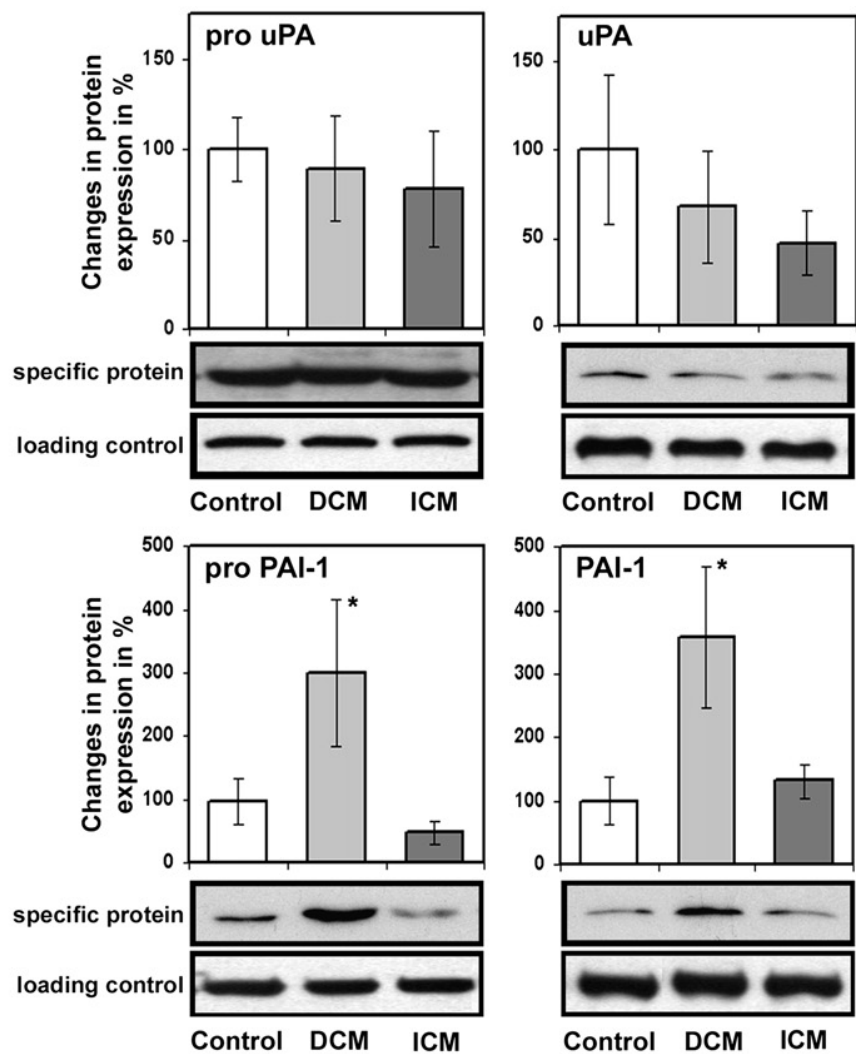

B

FIGURE 1. A, Quantification of mRNA expression levels of urokinase plasminogen activator $(u P A)$, tissue plasminogen activator $(t P A)$, urokinase plasminogen activator receptor $(u P A R)$, and plasminogen activator inhibitor $(P A I) 1$ and 2 in cardiac biopsy specimens of control subjects and patients with dilated cardiomyopathy $(D C M)$ and ischemic cardiomyopathy $(I C M)$. B, Quantification of protein expression levels of pro uPA, active uPA, latent PAI-1, and active PAI-1 in cardiac biopsy specimens of control subjects and patients with DCM and ICM. Results are expressed as means \pm standard deviations. $* P<.05$ compared with control subjects.

\section{PAI-1 Expression Increases 24 Weeks After Heart Transplantation in Patients With DCM}

We followed the mRNA expression pattern of PAI-1 in cardiac grafts of patients with DCM and ICM for 1 year after transplantation. In myocardial biopsy specimens obtained from patients with ICM who underwent transplantation, PAI-1 mRNA levels were not significantly different versus those of control subjects during the follow-up period. In contrast, PAI-1 mRNA expression was significantly increased in grafted hearts of patients with DCM compared with that seen in control subjects at 24 and 52 weeks after transplantation, although PAI-1 mRNA expression levels were not significantly different from those of control subjects at 1 to 12 weeks after transplantation (Figure 2, $A$ ).

Changes in PAI-1 serum concentrations were less striking than changes in myocardial tissue expression levels. However, the trend toward upregulated PAI-1 expression in patients with DCM at 24 and 52 weeks after transplantation was also present in serum. In patients with ICM and DCM, PAI-1 pretransplantation serum concentrations were not significantly different from those of control subjects.
After heart transplantation in patients with ICM, PAI-1 serum concentrations increased until week 3 compared with pretransplantation levels. At week 4, PAI-1 serum levels decreased in patients with ICM and remained stable thereafter at slightly higher levels than in control subjects (Figure 2,B). In contrast, in patients with DCM, PAI-1 serum levels increased after cardiac transplantation and remained upregulated during the first postoperative year compared with pretransplantation levels and levels seen in control subjects $(P<.05$; Figure $2, B)$. These data indicated differentially expressed PAI-1 levels after transplantation in patients with ICM compared with those seen in patients with DCM.

\section{PAI-1 Expression Is Independent of VEGF}

Stimulation with VEGF-A in DCM and ICM cardiac tissue cultures did not affect $U P A R$ and $P A I-1$ expression, whereas $u P A$ expression was upregulated in DCM and ICM versus untreated tissue cultures (Figure $3, A$ ). These experiments demonstrated that $P A I-1$ expression is independent of VEGF in DCM and ICM cardiac tissue cultures. 

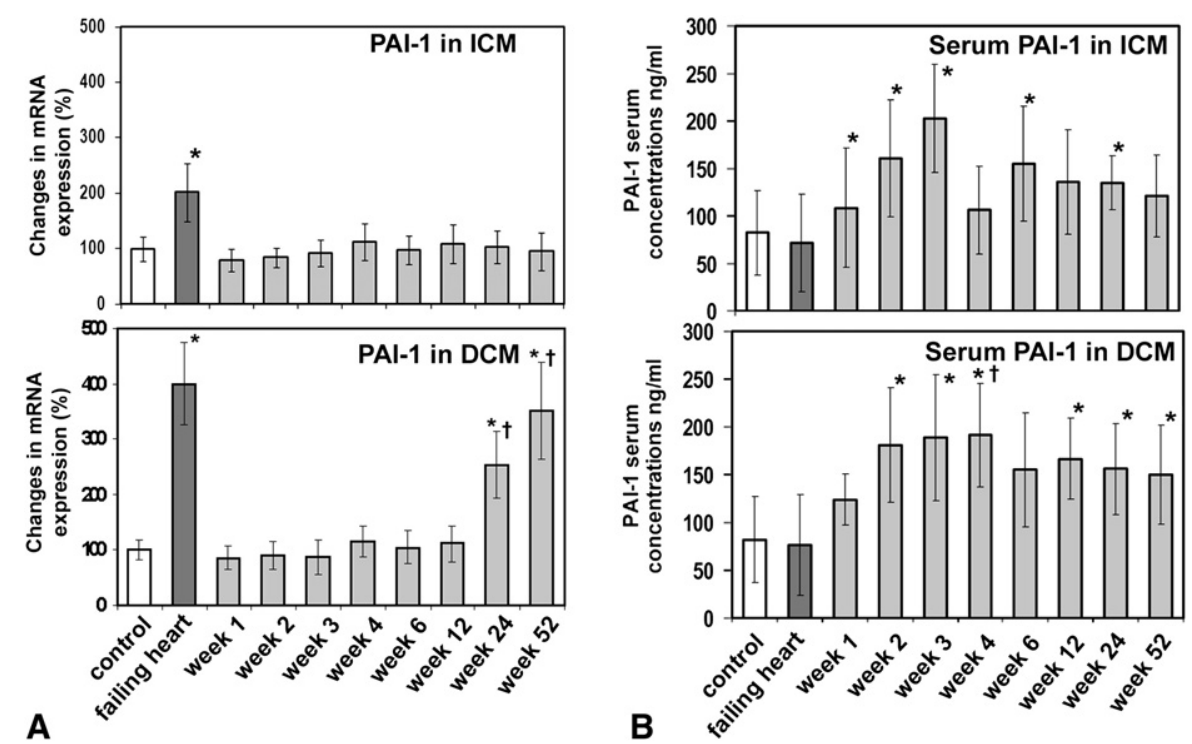

FIGURE 2. A, Quantification of plasminogen activator inhibitor (PAI-1) mRNA expression in cardiac biopsy specimens at 1 to 52 weeks after heart transplantation in patients with dilated cardiomyopathy $(D C M)$ and ischemic cardiomyopathy $(I C M)$. B, Quantification of PAI-1 serum levels at 1 to 52 weeks after heart transplantation of patients with DCM and ICM. Results are expressed as means \pm standard deviations. $* P<.05$ compared with control subjects. $\dagger P<.05$ compared with patients with ICM.

In addition, the isolated ECs, smooth muscle cells, and cardiomyocytes from cardiac tissue express $P A I-1, E T-1$ and TGFB (Table 3).

\section{Role of Patients' Sera in EC Activation In Vitro}

Because PAI-1 is involved in EC damage and because its serum levels increase in patients with DCM after
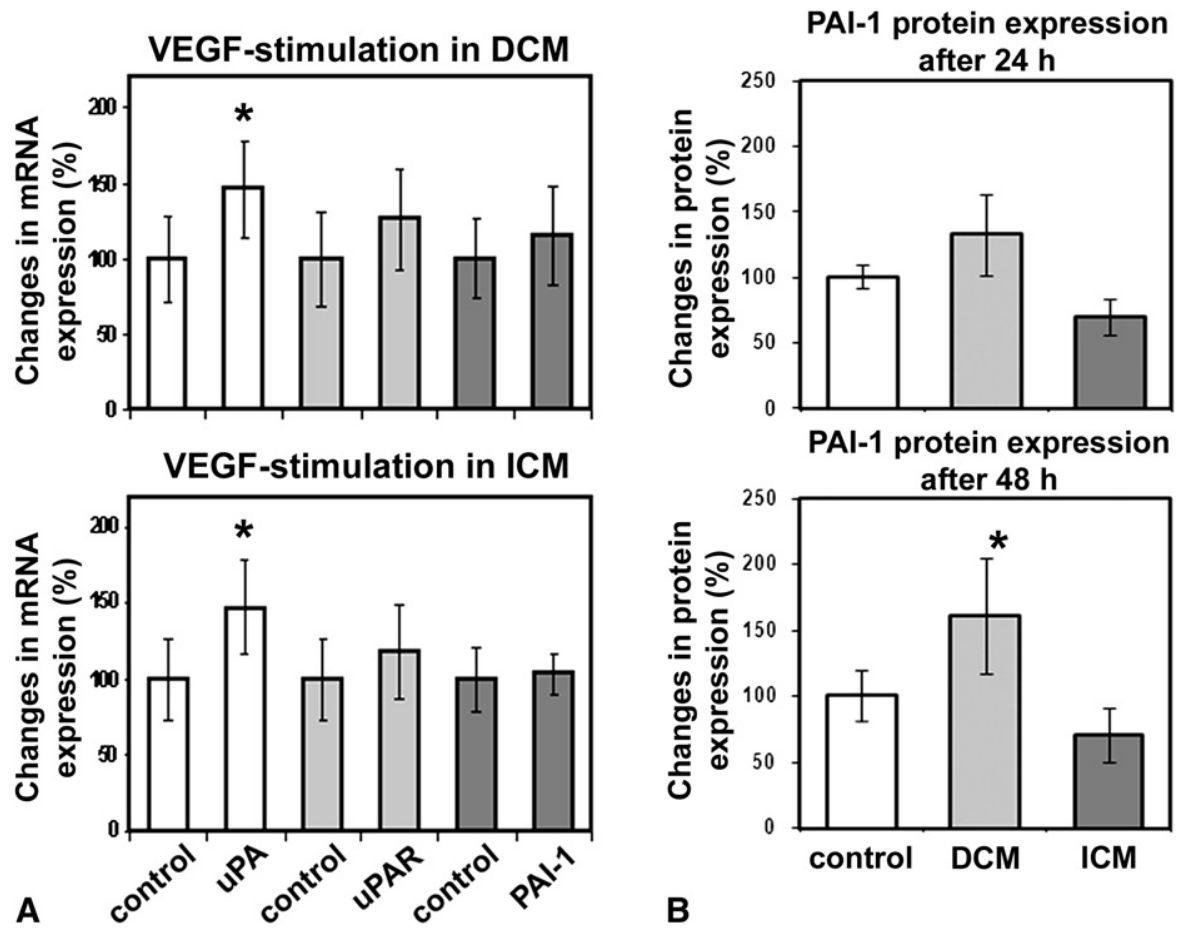

B

FIGURE 3. A, Vascular endothelial growth factor $(V E G F)$ stimulation in organ cultures isolated from patients with dilated cardiomyopathy $(D C M)$ and ischemic cardiomyopathy $(I C M)$. Quantification of mRNA expression of urokinase plasminogen activator $(u P A)$, urokinase plasminogen activator receptor $(u P A R)$, and plasminogen activator inhibitor $(P A I) 1$ is shown. B, Endothelial cells incubated with sera obtained from control subjects or patients with DCM or ICM for 24 and 48 hours. Quantification of protein expression of PAI-1 is shown. Results are expressed as means \pm standard deviations. $* P<.05$ compared with control subjects. 
TABLE 3. Expression of PAI-1, ET-1, and TGF- $\beta$ in different cardiac cell types

\begin{tabular}{lccc}
\hline & PAI-1 & ET-1 & TGF- $\beta$ \\
\hline Endothelial cells & + & + & + \\
Smooth muscle cells & + & + & + \\
Cardiomyocytes & + & + & + \\
\hline$P A I-1$, Plasminogen activator inhibitor $1 ; E T-1$, endothelin $1 ; T G F-\beta$, transforming \\
growth factor $\beta$.
\end{tabular}

transplantation, we examined the effect of sera from patients with DCM on VEGF-stimulated ECs.

Incubation of ECs with sera obtained from control subjects, patients with DCM, or patients with ICM does not affect basal protein expression of PAI-1 after 24 hours. However, after 48 hours, PAI-1 protein expression increases significantly $(P<.05)$ in ECs cultured with sera obtained from patients with DCM (Figure 3, $B$ ). These results designate that sera obtained from patients with DCM influence the expression level of PAI-1 in ECs.

\section{Sera of Patients With DCM Block EC Proliferation}

Stimulation of ECs with recombinant VEGF-A increased the cell proliferation rate when the ECs were cultured with medium containing sera obtained from patients with ICM (before transplantation and 4 and 52 weeks after transplantation) or control subjects $(P<.05)$. In contrast, stimulation with recombinant VEGF-A did not stimulate EC proliferation in ECs cultured with sera obtained from patients with DCM (before transplantation and 4 and 52 weeks after transplantation, Figure 4). These results indicate that sera of patients with DCM block VEGF-induced EC proliferation.

\section{VEGF Induces Signaling Target Genes in the Presence of Sera From Patients With ICM and DCM}

Stimulation of ECs cultured with medium containing sera obtained from patients with DCM and ICM or control subjects and supplemented with recombinant VEGF-A upregulated significantly the mRNA expression of 2 target genes of the VEGF signaling pathway: EGR- $1(P<.05)$ and $N A B-2$ $(P<.05$; Figure 5$)$. These experiments demonstrate that the VEGF signaling through its receptor was still inducible independent of patients' sera.

\section{DISCUSSION}

The results presented here were mainly based on posttransplantation mRNA levels, which might be a limitation.
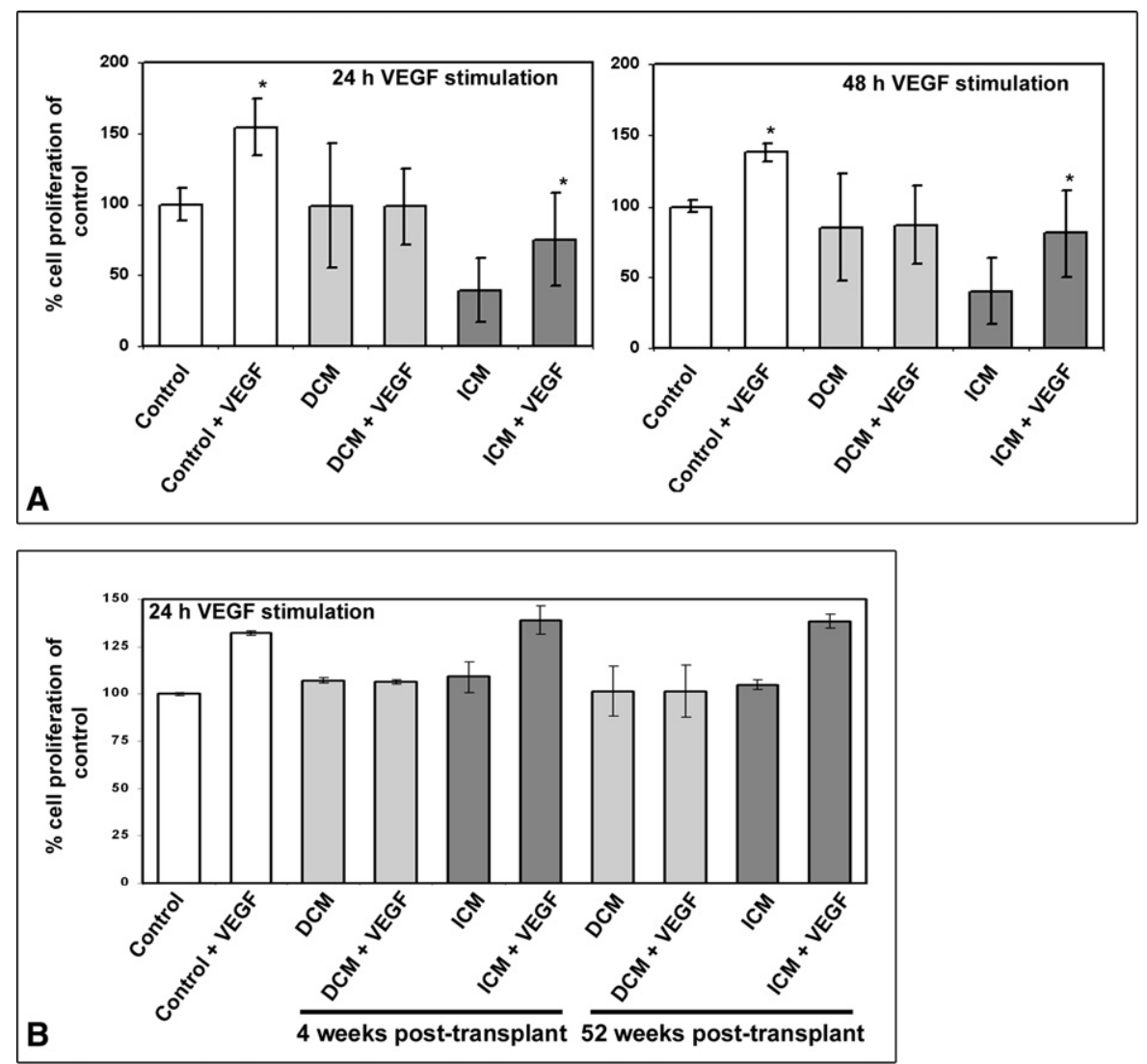

FIGURE 4. In vitro stimulation with vascular endothelial growth factor $(V E G F) \mathrm{A}$ of endothelial cells cultured with serum from control subjects and patients with dilated cardiomyopathy $(D C M)$ and ischemic cardiomyopathy $(I C M)$. A, Quantification of VEGF-A-stimulated cell proliferation of endothelial cells cultured with patients' pretransplantation sera. B, Quantification of proliferation in endothelial cells stimulated with VEGF-A cultured with patient serum obtained 4 and 52 weeks after transplantation. Results are expressed as means \pm standard deviations. ${ }^{*} P<.05$ compared with control subjects. 

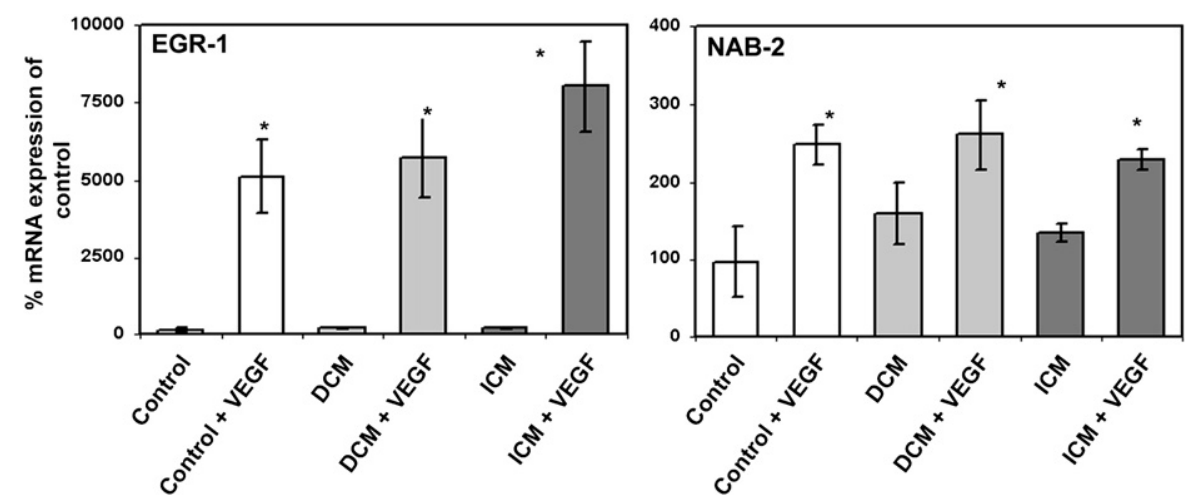

FIGURE 5. Quantification of mRNA expression of vascular endothelial growth factor (VEGF) target genes (EGR-1 and NAB-2) in VEGF-A-stimulated endothelial cells cultivated with patients' sera. Results are expressed as means \pm standard deviations. ${ }^{*} P<.05$ compared with control subjects. $D C M$, Dilated cardiomyopathy; ICM, ischemic cardiomyopathy.

However, determination of posttransplantation PAI-1 protein expression is nearly impossible because of the critically small size of endomyocardial biopsy specimens. The increased serum PAI-1 levels might indicate a general response to ischemia and reperfusion, and early expression of PAI-1 has been shown to protect against intimal proliferation associated with development of allograft vasculopathy in an experimental setting. ${ }^{15}$ The increasing and then persisting PAI-1 mRNA expression associated with its serum changes in patients with DCM might postulate a systemic hypofibrinolytic condition in cardiac transplant recipients with idiopathic DCM, and this condition becomes prominent at 6 months after transplantation. ${ }^{12,16}$ However, it must be noted that serum PAI-1 levels might not be fully representative of local (myocardial tissue) expression levels.

Several immunosuppressive drugs that are generally applied in cardiac transplant recipients have an effect on the expression of PAI-1. For example, steroid treatment has been related to increased serum PAI-1 levels independent of diagnosis. ${ }^{17}$ However, this might not play a role in the present study because all patients received steroid treatment as one part of their immunosuppressive regimen and no steroidfree protocols were applied. Moreover, the influence of cyclosporine or tacrolimus on PAI-1 serum levels might not be determined in this study because both protocols were applied irrespective of diagnosis in patients with ICM and DCM (Table 2). Posttransplantation statins were more frequently applied in patients with ICM than in patients with DCM, whereas angiotensin-converting enzyme inhibitors were applied in a similar percentage of patients in each disease group. Patients with valvular heart diseases (data not shown), who did not receive posttransplantation statins as frequently as patients with ICM patients, had a similar pattern of PAI-1 expression at 24 and 52 weeks after transplantation compared with that seen in patients with ICM. Because statins reportedly decrease PAI-1 expression, ${ }^{18}$ we cannot exclude that the PAI-1 results presented in our study might have been influenced by dissimilar use of statins.
PAI-1, in combination with ET-1 and TGF- $\beta$, are known indicators of EC damage, ${ }^{7,10}$ and PAI- 1 and ET- 19 expression levels increase in endomyocardial biopsies of patients with DCM at 6 and 12 months after transplantation. TGF- $\beta$ is involved in inflammatory reactions and in tissue remodeling, exerting its effects on composition of the ECM through expression of matrix metalloproteases. ${ }^{9,19}$ Moreover, TGF- $\beta$ regulates PAI-1 expression through the mitogen-activated protein kinase kinase extracellular signal-regulated kinase pathway. ${ }^{19}$ However, in patients with DCM, TGF- $\beta$ expression does not change in cardiac allografts after transplantation, ${ }^{9}$ so that PAI-1 expression in cardiac allografts of patients with DCM is apparently regulated independent of the TGF- $\beta$ signaling pathway.

Both ET-1 expression ${ }^{9}$ and PAI-1 expression increase at 6 months after transplantation, particularly in patients with DCM. ET-1 and PAI-1 are primarily expressed by nonmyocytes, particularly ECs and fibroblasts, and this might indicate a persisting pathology in patients with DCM undergoing cardiac transplantation that is not confined to the myocardium. This is further underlined by the result that pretransplantation and posttransplantation sera of patients with DCM inhibited VEGF-A-induced EC proliferation, although the intracellular signaling cascade for VEGF-A was responding. These findings suggest that a strong antiproliferative stimulus that is not yet identified and that acts independently of VEGF-A signaling is present in the sera of patients with DCM. In combination with ET-1, increased PAI-1 expression starting at 6 months after transplantation in patients with DCM might affect myocardial tissue remodeling, with increased ECM deposition and EC damage in the context of cardiac allograft fibrosis and microvascular remodeling in patients with DCM.

However, the molecular pathology described above should be considered with caution because in the posttransplantation setting patients with idiopathic DCM reveal no clinical peculiarities when compared with patients with ICM. In addition, patients with DCM have not been reported to have a shorter survival or more frequent events after 
transplantation compared with other patients with heart failure undergoing heart transplantation. However, it must be noted that the present study has served to further illuminate the previously identified vascular pathology in patients with $\mathrm{DCM}^{8,9,13}$ and to explain that in patients with DCM an additional, PAI-related but VEGF-independent system is operating that could contribute to this molecular pathology. Delineating how the molecular pathology identified in the present study might affect long-term clinical outcome in heart transplant recipients, particularly with regard to graft coronary artery vasculopathy, ${ }^{12}$ calls for randomized prospective studies, which are being planned currently in our center. Such studies might consider the fact that upregulated PAI-1 levels are associated with a poor prognosis in many cancer types and have been even considered as a prognostic marker in malignant diseases. ${ }^{6}$ Finally, we might specifically refer to the point that the observed pathology of the PAI-1 system in this study could have been considered DCM unspecific. However, the results on PAI-1 in patients with heart failure due to valvular diseases point to the fact that the results are DCM specific and in line with our previous observations, ${ }^{8,9,19}$ suggesting a vascular-related pathology for idiopathic DCM.

\section{References}

1. Devy L, Blacher S, Grignet-Debrus C, Bajou K, Masson V, Gerard RD, et al. The pro- or antiangiogenic effect of plasminogen activator inhibitor 1 is dose dependent. FASEB J. 2002; 16:147-54.

2. Chorostowska-Wynimko J, Skrzypczak-Jankun E, Jankun J. Plasminogen activator inhibitor type-1 controls the process of the in vitro sprout formation. J Physiol Pharmacol. 2004;55(suppl 3):49-56.

3. Demyanets S, Kaun C, Rychli K, Rega G, Pfaffenberger S, Afonyushkin T, et al. The inflammatory cytokine oncostatin $\mathrm{M}$ induces PAI-1 in human vascular smooth muscle cells in vitro via PI3 kinase and ERK 1/2 dependent pathways. Am J Physiol Heart Circ Physiol. 2007;293:H1962-8.

4. Moriwaki H, Stempien-Otero A, Kremen M, Cozen AE, Dichek DA. Overexpression of urokinase by macrophages or deficiency of plasminogen activator inhibitor type 1 causes cardiac fibrosis in mice. Circ Res. 2004;95:637-44.

5. Heymans S, Lupu F, Terclavers S, Vanwetswinkel B, Herbert JM, Baker A, et al. Loss or inhibition of uPA or MMP-9 attenuates LV remodeling and dysfunction after acute pressure overload in mice. Am J Pathol. 2005;166: 15-25.

6. Croucher DR, Saunders DN, Lobov S, Ranson M. Revisiting the biological roles of PAI2 (SERPINB2) in cancer. Nat Rev Cancer. 2008;8:535-45.

7. Kathiresan S, Gona P, Larson MG, Vita JA, Mitchell GF, Tofler GH, et al. Crosssectional relations of multiple biomarkers from distinct biological pathways to brachial artery endothelial function. Circulation. 2006;113:938-45.

8. Schäfer R, Abraham D, Paulus P, Blumer R, Grimm M, Wojta J, et al. Impaired VE-cadherin/beta-catenin expression mediates endothelial cell degeneration in dilated cardiomyopathy. Circulation. 2003;108:1585-91.

9. Aharinejad S, Krenn K, Paulus P, Schäfer R, Zuckermann A, Grimm M, et al. Differential role of TGF-beta1/bFGF and ET-1 in graft fibrosis in heart failure patients. Am J Transplant. 2005;5:2185-92.

10. Funauchi M, Shimadsu H, Tamaki T, Yamagata T, Nozaki Y, Sugiyama M, et al. Role of endothelial damage in the pathogenesis of interstitial pneumonitis in patients with polymoysitis an dermatomyositis. J Rheumatol. 2006;33: 903-6.

11. Benza RL, Cavender MA, Barchue J, Tallaj JA, Bourge RC, Kirklin JK, et al Alterations in the fibrinolytic cascade post-transplant: evidence of a bimodal expression pattern. J Heart Lung Transplant. 2007;26:494-7.

12. Warshofsky MK, Wasserman HS, Wang W, Teng P, Sciacca R, Apfelbaum M, et al. Plasma levels of tissue plasminogen activator and plasminogen activator inhibitor-1 are correlated with the presence of transplant coronary artery disease in cardiac transplant recipients. Am J Cardiol. 1997;80:145-9.

13. Wiesbauer F, Kaun C, Zorn G, Maurer G, Huber K, Wojta J. HMG CoA reductase inhibitors affect the fibrinolytic system of human vascular cells in vitro: a comparative study using different strains. Br J Pharmacol. 2002;135:284-92.

14. Zins K, Abraham D, Sioud M, Aharinejad S. Colon cancer cell-derived tumor necrosis factor-alpha mediates the tumor growth-promoting response in macrophages by up-regulating the colony-stimulating factor-1 pathway. Cancer Res. 2007;67:1038-45.

15. Benza RL, Anderson PG, Lyle K, Barchue J, de Oliveira AL, Cavender MA, et al. Donor PAI-1 expression inhibits the intimal response of early allograft vascular disease. J Heart Lung Transplant. 2003;22:515-8.

16. Benza RL, Cavender MA, Barchue J, Tallaj JA, Bourge RC, Kirklin JK, et al. Alterations in the fibrinolytic cascade post-transplant: evidence of a bimodal expression pattern. J Heart Lung Transplant. 2007;26:494-7.

17. Sartori TM, Maurizio PG, Sara P, Ugolino L, Annalisa A, Panagiotis T, et al Relation between long-term steroid treatment after heart transplantation, hypofibrinolysis and myocardial microthrombi generation. J Heart Lung Transplant. 1999; 18:693-700.

18. Wilkins-Port CE, Higgins CE, Freytag J, Higgins SP, Carlson JA, Higgins PJ PAI-1 is a critical upstream regulator of the THF-b/EGF-induced invasive Phenotype in mutant p53 human cutaneous squamous cell carcinoma. J Biomed Biotechnol. 2007;2007:85208.

19. Abraham D, Hofbauer R, Schäfer R, Blumer R, Paulus P, Miksovsky A, et al Selective downregulation of VEGF-A(165), VEGF-R(1), and decreased capillary density in patients with dilative but not ischemic cardiomyopathy. Circ Res. 2000; 87:644-7. 